\title{
Professional Commitments and Pressure of Obedience in Mediating on the Effect of Time Budget Pressure in Quality Audits
}

\author{
Ida Bagus Gede Putra Wibawa Kesuma ${ }^{a}$
}

A.A.N.B. Dwirandra ${ }^{b}$

\section{Article history:}

Received: 27 July 2018

Accepted: 30 November 2018

Published: 29 January 2019

\section{Keywords:}

audit quality;

empirical evidence;

pressure of obedience;

professional commitment;

time budget pressure;

\begin{abstract}
The purpose of this study is to provide empirical evidence of the ability of professional commitment and pressure of obedience in moderating the effect of time budget pressure on audit quality. Auditors working in the Public Accounting Firm registered in the Province of Bali were used as populations using purposive sampling according to the criteria set. The data analysis technique used is the moderated regression analysis (MRA). The results showed that time budget pressure had a significant negative effect on audit quality and showed that professional commitment weakened the negative influence of time budget pressure on audit quality and pressure of obedience to strengthen the negative influence of time budget pressure on audit quality.
\end{abstract}

2454-2261 ${ }^{\odot}$ Copyright 2019. The Author. This is an open-access article under the CC BY-SA license (https://creativecommons.org/licenses/by-sa/4.0/) All rights reserved.

\section{Author correspondence:}

Ida Bagus Gede Putra Wibawa Kesuma,

Faculty Economic and Business of Udayana University, Bali, Indonesia.

Email address:ib_wib@yahoo.com

\section{Introduction}

The shareholders and management generally designate a public accounting firm related to the differences in information obtained (Puspanita, 2009). And to convince investors and other parties of the quality of information and reduce the occurrence of differences in the information that can be detrimental, then an independent and competent party is needed, namely audit services from the Public Accounting Firm (KAP).

In fact, the quality of an auditor is questioned where there are various cases of unhealthy practices regarding accounting for companies that have been audited by public accountants and even obtain unqualified opinions. This condition certainly gives a big risk to the public accounting profession whose existence is determined by the opinions given on audited financial statements (Dwirandra et al., 2017). This is inseparable from the behavior of an auditor in carrying out his duties to audit a company's financial statements where such behaviors constitute a serious threat to audit quality because audit evidence collected during the implementation of audit procedures is incompetent and

${ }^{a}$ Faculty Economic and Business of Udayana University, Bali, Indonesia

${ }^{\mathrm{b}}$ Faculty Economic and Business of Udayana University, Bali, Indonesia 
sufficient as an adequate basis for auditors to express their opinions regarding the fairness of audited financial statements (Otley \& Pierce, 1996a; Herrbach, 2001).

Individual behavior is a reflection of the personality side while situational factors that occur at that time will encourage someone to make a decision (Jansen \& Glinow, 1985). From this opinion, it can be concluded that the behavior of dysfunctional audit (dysfunctional audit behavior) can be caused by factors of personal characteristics of the auditor (internal factors) and situational factors when conducting an audit (external factors). Therefore the search for both internal and external factors that influence the behavior of dysfunctional audits is important to be carried out. Actually, there are several factors that should be suspected of contributing to dysfunctional audit behavior but in this study will focus on the role of external time budget pressure factors on dysfunctional audit behavior. Focusing on external factors, namely time budget pressure in this study in addition to conceptual, logical thinking and empirical studies that with time budget constraints will lead to pressure which leads to acceptance of a auditor's deviant behavior which will affect the provision of opinions on audited financial statements, besides that Coram et al., (2004) in his study found 106 senior auditors explained in general that the time budget pressure had the greatest influence on the behavior of dysfunctional audits so that the resulting audit quality was low.

Time budget pressure according to Nirmala \& Cahyonowati (2013) is a condition that shows auditors are required to make efficiency on the time budget that has been prepared or there is a very tight and rigid budget time discussion. Furthermore, Dwimilten et al., (2015) time budget pressure is a part of the planning used by auditors who set guidelines in hours for each section of the audit. The number of hours must be allocated by preparing a work schedule that shows who is carrying out and what and how long it is done. Then the total hours are budgeted in the main categories in the audit procedure and arranged in the form of a weekly schedule. Based on the above explanation, it can be concluded that time budget pressure is a situation where an auditor is under a plan when conducting an audit program where the pressure is a time limit.

Several previous studies have examined the effect of time budget pressure on audit quality and showed inconsistent results. The study conducted by Arisinta (2013) found that the higher the budgetary pressure time felt by the auditor, the higher the tendency of an auditor to perform dysfunctional audit behavior so as to reduce audit quality. Sudirjo (2013) states that the higher the time budget pressure, the higher the auditor's tendency to conduct dysfunctional audit behavior. This result is in line with the research of Ningsih (2013); Kurnia (2014); Nurhayati (2015) and Nurhasanah et al., (2018). The study states that the higher the time budget pressure felt by the auditor can cause the low quality of the audit produced. The research contradicts the research conducted by Arisinta (2013); Jelista (2015); Atiqoh (2016) and Anugrah (2017) which states that time budget pressure has a positive and significant effect on audit quality. The study states that the higher the time budget pressure given is felt by the auditor, the higher the auditing quality.

Based on the results of previous studies that are inconsistently suspected there are other factors that have influence independent variables on the dependent variable. Govindarajan (1986) states that the possibility of the absence of unity of research results depends on certain factors or better known as contingency factors. Murray (1990) explains that in order to reconcile conflicting results a contingency approach is needed to identify other variables that act as moderators or mediators in the research model.

Conceptually and the results of research there are several variables that are allegedly able to moderate the influence of time budget pressure on audit quality, where two of them, professional commitment and pressure of obedience. Professional commitment is an important factor that influences auditor behavior (Shaub et al., 1993). Professional commitment is the level of individual loyalty to the profession as perceived in the individual (Larkin, 1990). A person's commitment to his profession is manifested in the following three characteristics; first, an acceptance of professional goals and values; secondly, a willingness to make a strong effort in the interests of the profession and third, a desire to maintain and maintain membership in the profession (Aranya \& Ferris, 1984). Nur Rochman et al., (2016) and Wiguna's (2016) study found that professional commitment had a positive and significant effect on audit quality, which meant that the higher the auditor's commitment to the profession the higher the audit quality produced. So based on this explanation, it can be said whether an auditor with high professional commitment is able to reduce the negative influence of time budget pressure on audit quality, is an interesting statement that will later be revealed in this study.

Furthermore, the pressure of obedience is used as a moderating variable, where the performance of the auditor itself can be influenced by social pressure and social pressure itself is divided into two types, namely pressure of obedience and pressure of conformity. The pressure of obedience is the pressure received by the auditor in dealing with superiors and clients to take deviant actions from ethical standards (Jamilah et al., 2007). An auditor will feel under pressure of obedience when getting orders from superiors or from clients to do something they want where the 
possibility of this is contrary to the professional ethics standards of the auditor itself. In the end, with the higher pressure faced by auditors, the decisions taken by auditors tend to be less precise (Evi et al., 2014). Thus, based on the above explanation it can be said that pressure of obedience influences the behavior of an auditor. Furthermore, it can be assumed that the pressure of obedience strengthens the influence of time budget pressure on audit quality, which is quite interesting to confirm its significance in this study.

It is different from the research of Indraswari \& Budiartha (2016); Andani \& Mertha (2014), Martini (2017) which in their study only looked at one dysfunctional factor in its impact on audit quality, namely premature sign off but in this study examined auditor dysfunctional behavior rather than only stopping audit procedures but actions such as superficial reviews, not extending the scope of evidence collection and so on as explained above and not only that this study also focuses on testing the ability of several contingency factors, such as professional commitment (internal factors) and pressure of obedience (external factors) in moderating the effect of time budget pressure on audit quality, where the two moderating variables aside from being the option of answers to the controversy of the results of previous studies as well as to distinguish this research from previous research.

\section{Literature Review}

\section{a) Attribution Theory}

This theory describes a person's behavior in interpreting an event, studying how one also interprets the reason or cause of his behavior (Steers, 1998 in Hudayati, 2002). The argument of this theory is that a person's behavior is determined by a combination of internal forces, namely factors that come from within a person such as ability, knowledge, effort; while external forces are external factors such as luck, opportunity, and environment (Frtiz Heider, 1958 in Hudayati, 2002). The implementation of attribution theory in this study is the use of professional commitment (internal strength) and pressure of obedience (external power), professional commitment variables play a role in avoiding an auditor in performing dysfunctional behavior when he has high commitment and vice versa. Furthermore, the use of obedience pressure will actually make an auditor perform deviant behavior wherein the presence of time budget pressures and added obedience pressures, there is a high possibility of dysfunctional behavior.

\section{b) Job Stress Model Theory}

Stress as an adjustment response, mediated by individual differences and/or psychological processes resulting from each environmental request, situation, or event that determines excessive psychological and/or physical demands on someone (Gibson et al., 1995). Stress is a condition where a person feels pressure on himself and his soul and is beyond the limits of his abilities. This stress is not something that comes just like that, but the cause comes or arises, generally followed by factors that affect a person's psyche, and events that occur outside of his ability to ultimately suppress his soul (Farmi, 2014).

c) Transactional Process Theory

This theory was put forward by (Lazarus, 1995) which states that stress perceived individually is an interaction between external factors (stressors) and internal factors (individual characteristics). According to this theory, the relationship between individuals and their environment is dynamic, dependent under certain conditions and personal contexts. In other words, perceived stress levels and actions chosen individually to deal with stressors are influenced by individual characteristics.

This theory underlies the influence of individual auditor car-criticism on perceived time budget pressure where according to this theory, stress (stress) that individuals perceive the same conditions can differ depending on their individual characteristics. Specifically, the perception and assessment of an auditor on the time budget allocated for the implementation of an audit program are influenced by the auditor's individual characteristics where this condition further influences the tendency of an auditor to take dysfunctional audit actions in the implementation of the audit program.

\section{d) Contingency Approach}

This approach can be used in analyzing the design and management accounting system to provide information that can be used for various purposes for the company. The researchers used this approach by including factors that should be considered in the design of the study. The researchers were interested in using a contingency approach because they wanted to know whether the reliability level of the independent variable always had the same effect on

Kesuma, I. B. G. P. W., \& Dwirandra, A. (2019). Professional commitments and pressure of obedience in mediating on the effect of time budget pressure in quality audits. International Research Journal of Engineering, IT \& Scientific Research, 5(1), 27-38. https://doi.org/10.21744/irjeis.v5n1.587 
the dependent variable. The conjecture that there are other situational factors that might interact with each other in influencing certain situations. Some research in the field of accounting uses a contingency approach to look at the relationship of contextual variables such as environmental uncertainty (Otley, 1980).

e) Dysfunctional Audit Quality Behavior

The behavior of dysfunctional audits results in unreliable evidence collected during the audit so that the evidence is incompetent and sufficient as an adequate basis for the auditor to detect errors and irregularities found in the financial statements audited (Silaban, 2009). According to Silaban (2009) actions such as premature termination of audit procedures, accepting weak client explanations, superficially reviewing client documents, failing to examine the suitability of accounting principles applied by clients, and reducing audit work from what should be done are actions that directly reduce audit quality.

f) Audit Quality

Audit quality is the conduct of audits carried out according to standards so that auditors are able to disclose and report if there are violations committed by the client, the standards governing the conduct of audits in Indonesia are the Professional Standards of Public Accountants (Tarigan \& Susanti, 2013). According to this standard that audits carried out by auditors are said to be of high quality if they meet auditing standards and quality control standards wherein measuring audit quality the researchers use different approaches one approach that is used is an outcomeoriented approach and an oriented approach in the process (process oriented).

g) Time Budget Pressure

A tight audit time budget has an impact on the auditor which can result in an auditor feeling the time budget pressure in the implementation of the audit program due to an imbalance between the available audit time budget and the time needed to complete the audit program. When facing this pressure, the auditor will provide a response in two ways, namely, a response that is positive (functional) or a negative response (dysfunctional). Positive type (functional) is the auditor's behavior to work harder and use the best time, while the negative type (dysfunctional) is to make a decrease in audit quality. In this study extends research on the factors that influence the dysfunctional behavior of auditors by simultaneously testing the individual characteristics of auditors and external forces on perceived time budget pressure on dysfunctional audit behavior.

\section{h) Professional Commitment}

An auditor's commitment to his profession is important to the behavior of auditors in carrying out their audit duties. Seeing the existence of Professional commitments found outside accounting, according to Hall et al., (2005) propose multi-dimensional Professional commitment to the accounting profession. These three dimensions are; commitment to professional affective (affective professional commitment), continuous professional commitment (continuance professional commitment), and normative professional commitment (normative professional commitment). Affective professional commitment (KPA) relates to the extent to which individuals "want to be" in a profession (Meyer et al., 1993). The commitment the auditor's profession in effective form can arise as a resulting exchange of positive experiences felt from the profession or development Professional expertise (Hall et al., 2005).

i) Pressure of Obedience

Obedience pressure is one of the factors that influence the existence of dysfunctional behavior of auditors. This happens when an auditor is faced with a dilemma of fulfilling his professional standards. Obey or not obey the will of the client or his boss. Based on this, an auditor is often faced with a dilemma of applying professional standards when making a decision (Jamilah et al., 2007). An auditor will issue an opinion on the fairness of the financial statements where this opinion must be in accordance with the actual situation. The auditor cannot simply issue an unqualified opinion without adequate evidence. Compliance pressure can produce variations in the assessment of financial statements by auditors and increase the likelihood of violations of ethical standards and Professionals (Yendrawati \& Mukti, 2015). 


\section{Materials and Methods}

This study aims to examine the ability to moderate professional commitment and pressure of obedience on the effect of time budget pressure on audit quality. The population in this study were all auditors at the Bali Provincial Public Accountants Office. Samples were selected by purposive sampling method with the criteria of respondents not limited by the auditor's position in KAP (partner, manager, senior and staff auditor) so that all auditors working in KAP could be included as respondents. The hypothesis was tested by the data analysis technique used in this study is multiple linear regression analysis.

\section{Results and Discussions}

The regression analysis model used in this study is Simple Regression Analysis and Moderated Regression Analyzes (MRA) with the help of IBM SPSS version 22 program. The test results are shown in Table 1.

Table 1

Regression Analysis Result

\begin{tabular}{lll}
\hline Variable & Beta & Sig. \\
\hline (Constant) & 62,738 & 0,000 \\
$\mathrm{X}_{1}$ & $-0,943$ & 0,000 \\
\hline
\end{tabular}

Primary Data, 2018

Based on table 1, so regression analysis equation formed as follows:

$$
\mathrm{Y}=62,738-0,943 \mathrm{X}_{1}+2,852
$$

Furthermore, based on table 2. it can be seen the results of the hypothesis test the moderating effect of the Professional Commitment and Pressure of obedience variables on the influence of Time Budget Pressure on the Audit Quality with the following results:

Table 2

MRA Testing Result

\begin{tabular}{lll}
\hline Variable & Beta & Sig. \\
\hline (Constant) & 68,847 & 0,000 \\
$\mathrm{X}_{1}$ &,- 236 &, 479 \\
$\mathrm{X}_{2}$ &, 012 &, 930 \\
$\mathrm{X}_{3}$ & $-1,014$ &, 003 \\
$\mathrm{X}_{1} \mathrm{X}_{2}$ &,- 011 &, 026 \\
$\mathrm{X}_{1} \mathrm{X}_{3}$ &, 026 &, 027 \\
\hline
\end{tabular}

Primary Data, 2018

The results of hypothesis testing show evidence that time budget pressure has a negative and significant influence on audit quality. This result means that the higher the time budget pressure felt by an auditor, the lower the quality audit produced and the lower the time budget pressure perceived by an auditor, the higher the quality audit produced. The results of this hypothesis testing support the results of research by Haribowo \& Marzuki (2014); Pramudianti \& Setiawan (2016) and Devi \& Ramantha (2017) which show the negative effect of time budget pressure on audit quality. The results of this study support the work stress model theory where tight time budgets can cause stress to the auditor in carrying out his work which will then influence attitudes, intentions, and behaviors in the implementation of the audit program. And based on that, the resulting audit quality is low.

The results of this study indicate that professional commitment is able to moderate the effect of time budget pressure on audit quality with categories as pure moderates and B2 values of - 0.011 and significance of 0.026 so that the second hypothesis (H2) is accepted. Based on the results, it can be said that professional commitment is able to

Kesuma, I. B. G. P. W., \& Dwirandra, A. (2019). Professional commitments and pressure of obedience in mediating on the effect of time budget pressure in quality audits. International Research Journal of Engineering, IT \& Scientific Research, 5(1), 27-38. https://doi.org/10.21744/irjeis.v5n1.587 
weaken the negative influence of time budget pressure on audit quality. When an auditor feels a high time budget pressure, his tendency to behave defiantly increases, but if the professional commitment possessed by an auditor is high, it can reduce the auditor's desire to carry out such behavior so that the resulting audit quality is still high. The results of this study are in line with the research conducted by Intan Wintari et al., (2015); Nur Rochman (2016) and Meilda Wiguna (2016) who found that the higher the professional commitment an auditor possesses the higher audit quality.

Professional commitment is very important for a profession where it can be known to what extent a person wants to be in a profession, remain in a profession and an obligation to be in a profession (Hall et al., 2005). The results of this study reflect the theory put forward by (Lazarus, 1995) which states that stress perceived individually is an interaction between external factors (stressors) and internal factors (individual characteristics). In other words, perceived stress levels and actions individuals chosen to overcome stressors are influenced by individual characteristics and professional commitment is one of the characteristics that sufficiently gives an impact in overcoming work stress and taking an action. In this study, it is seen that an auditor with high professional commitment will tend not to do deviant behavior under time budget pressure resulting in high audit quality.

The results of this study show that the pressure of obedience is able to moderate the effect of time budget pressure on dysfunctional audit behavior with categories as quasi-moderates and B3 values of 0.026 and significance of 0.027 so that the third hypothesis (H3) is accepted. Based on the results, it can be said that the pressure of obedience can strengthen the negative influence of time budget pressure on audit quality. When an auditor feels a high time budget pressure, the tendency to commit deviant behavior will also increase where the possibility of doing this behavior will increase when an auditor also feels a high pressure of obedience resulting in low audit quality. These results are in line with the previous research of Maria \& Elisa Tjondro (2014); Ayudia et al., (2015), and Rosadi \& Waluyo (2017) who in their study found that pressure of obedience negatively affected audit judgment so that they behaved defiantly during the audit program and cause the resulting audit quality to be low.

The pressure of obedience is the pressure obtained from the boss and the entity being examined. If an entity expects a matter that is different from the expectations of an auditor, then a pressure arises that is felt by the auditor where when that happens the entity examined will try to pressure the auditor to equalize his expectations. So that in this case the entity being examined will influence the audit process carried out by the auditor and press the auditor to take actions that violate the inspection standards. The pressure of obedience from superiors can also cause the auditor to behave deviant in taking actions and decisions during the audit program. The existence of sanctions on the orders of superiors, if it is not executed, causes the auditor to make the wrong decision, namely obeying the orders of the superior.

\section{Conclusion}

Time budget pressure has a significant negative effect on audit quality. This shows that the higher the time budget pressure felt by the auditor causes the lower the quality of the audit produced. Professional commitment weakens the effect of negative time budget pressure on audit quality. This shows that a high professional auditor commitment will weaken the auditor's intention to behave in a disastrous manner when he feels a high time budget pressure so that the audit quality is high. However, if the professional commitment of an auditor is low, the tendency to deviate will also increase when the perceived time budget pressure also increases so that the resulting audit quality is low. A pressure of obedience strengthens the negative influence of time budget pressure on audit quality. This shows that when the pressure of obedience and time budget pressure perceived by an auditor increases, the tendency to conduct deviant behavior increases so that the resulting audit quality becomes low.

\section{Suggestion}

In this study only included one internal factor and two external factors that influence the auditor's intention to behave defiantly when he is under pressure so that an auditor feels work stress. This research can open opportunities for other researchers to include several factors both internal and external so that they can see the cause of an auditor behaving more deeply. It is good for future research to focus more on internal factors (individual characteristics) in responding to a pressure that causes the auditor to take a deviant decision. The characteristics of the individual in question, for example, whether the decision making carried out provides an advantage to him, which is in accordance 
with the theory in psychology, namely Cognitive Moral Development (Teleological Theory and Deontological Theory).

Researchers use survey methods with questionnaire techniques to collect data so that they have limitations in disclosing deep problems related to stress auditors. Subsequent research can be done with direct interview techniques to get more in-depth disclosures about auditor behavior.

The results of this study found that there was an auditor response from the Public Accountant Office in Bali that was not considered from the time budget pressure, namely doing dysfunctional audit behavior (dysfunctional audit behavior) which affected the low quality of the audit produced. This can be seen from the respondent's answer which relates when the auditor's performance appraisal only sees the suitability of the audit assignment with the budget for giving them dysfunctional behavior, namely by reducing the audit work from what should be done as stipulated in the audit program. Based on this, it is better for the Public Accountant Office in Bali to be more objective in assessing the performance of an auditor who does not only see the suitability of audit assignments with a time budget. To avoid a response that is not expected from budgetary pressures, it is better for a public accounting firm in Bali to add a number of supervisors, which based on the data collection process found that there are only 4 public accounting offices in Bali. The addition of the supervisor is expected to be able to better control and oversee the course of the audit program.

The results also indicate that an increase in auditor welfare needs to be done for auditors of the Public Accountant Office in Bali such as improving the incentive scheme so that auditors will be more committed to their profession and also feel that continuing their career as an auditor is the right decision. It is good for a public accounting firm in Bali to use the software in conducting an audit program so that the implementation of the program is well structured and planned in order to avoid pressure from the time budget so that it has an impact on the auditor's bad response. Based on the results of this study it can also be seen that in the process of employee recruitment (auditors) it is better to carry out a fairly rigorous selection process and it is better to adopt the employee recruitment process as carried out by the Big Four public accounting firm and aim to obtain quality human resources and has a commitment to the profession so as to avoid deviant behaviors.

Conflict of interest statement and funding sources

The authors declared that they have no competing interest. The study was financed by the authors.

Statement of authorship

The authors have a responsibility for the conception and design of the study. The authors have approved the final article.

\section{Acknowledgments}

The authors would like to thank the lectures and the Head of the Master Program of the Accounting Department at the Faculty of Economics and Business at Udayana University who supported this paper could be completed. And thank the reviewers and the editorial team for their valuable support, time and advice.

Kesuma, I. B. G. P. W., \& Dwirandra, A. (2019). Professional commitments and pressure of obedience in mediating on the effect of time budget pressure in quality audits. International Research Journal of Engineering, IT \& Scientific Research, 5(1), 27-38. https://doi.org/10.21744/irjeis.v5n1.587 


\section{References}

Asgari, A. (2013). Core Self-Evaluations, General Health and Stress among College Students. International Journal of Research in Organizational Behaviour and Human Resource Management, 1(4), 230.

Bandura, A. (1993). Perceived self-efficacy in cognitive development and functioning. Educational psychologist, 28(2), 117-148. https://doi.org/10.1207/s15326985ep2802_3

Barrett, M. J. (2004). Tax services as a Trojan horse in the auditor independence provisions of SarbanesOxley. Mich. St. L. Rev., 463. https://heinonline.org/

Baumeister, R. F., Campbell, J. D., Krueger, J. I., \& Vohs, K. D. (2003). Does high self-esteem cause better performance, interpersonal success, happiness, or healthier lifestyles?. Psychological science in the public interest, 4(1), 1-44. https://doi.org/10.1111\%2F1529-1006.01431

Bersamin, K. K. (2006). Moderating job burnout: An examination of work stressors and organizational commitment in a public sector environment. http://dspace.spu.ac.th/handle/123456789/2566

Broucek, W. G. (2005). An examination of core self-evaluations (CSE) in an academic setting: Does CSE generalize to students. Journal of College Teaching and Learning, 2(2), 59-62. https://doi.org/10.19030/tlc.v2i2.1779

Brunborg, G. S. (2008). Core self-evaluations: A predictor variable for job stress. European Psychologist, 13(2), 96102. https://doi.org/10.1027/1016-9040.13.2.96

Caponetti, A. R. (2012). The correlates of work role stress with employee burnout, engagement. https://trace.tennessee.edu/utk_graddiss/1407/

Chai, M. S., \& Low, C. S. (2015). Personality, coping and stress among university students. American Journal of Applied Psychology, 4(3-1), 33-38. https://doi.org/10.11648/j.ajap.s.2015040301.16

Chye Koh, H., \& Woo, E. S. (1998). The expectation gap in auditing. Managerial auditing journal, 13(3), $147-154$. https://doi.org/10.1108/02686909810208038

Cohen, S., Kamarck, T., \& Mermelstein, R. (1983). A global measure of perceived stress. Journal of health and social behavior, 385-396. https://doi.org/10.2307/2136404

Couper, I. D. (2005). Approaching burnout. South African Family Practice, 47(2), 5-8. https://doi.org/10.1080/20786204.2005.10873179

Dumitru, V. M., \& Cozman, D. (2012). The relationship between stress and personality factors. Human and Veterinary Medicine, 4(1), 34-39. http://www.hvm.bioflux.com.ro/docs/HVM_4.1.7.pdf

Fanani, Z., Hanif, R. A., \& Subroto, B. (2008). Pengaruh Struktur Audit, Konflik Peran, dan Ketidakjelasan Peran Terhadap Kinerja Auditor. Jurnal Akuntansi dan Keuangan Indonesia, 5(2), 139-155. http://dx.doi.org/10.21002/jaki.2008.07

Feist, J., \& Feist, G. J. (2008). Theories of Personality edisi keenam. Yogyakarta: Pustaka Belajar.

Fisher, R. T. (2001). Role stress, the type A behavior pattern, and external auditor job satisfaction and performance. Behavioral Research in Accounting, 13(1), 143-170. https://doi.org/10.2308/bria.2001.13.1.143

Folkman, S., Lazarus, R. S., Dunkel-Schetter, C., DeLongis, A., \& Gruen, R. J. (1986). Dynamics of a stressful encounter: cognitive appraisal, coping, and encounter outcomes. Journal of personality and social psychology, 50(5), 992. https://psycnet.apa.org/doi/10.1037/0022-3514.50.5.992

Furqon. (2009). Statistika Terapan untuk Penelitian. Bandung: Penerbit Alfabeta.

Gbadamosi, G., \& Ross, C. (2012). Perceived stress and performance appraisal discomfort: The moderating effects of core self-evaluations and gender. Public Personnel Management, 41(4), $637-659$. https://doi.org/10.1177/009102601204100404

Ghozali, I. (2011). Analisis Multivariate SPSS. Semarang: Badan Penerbit Universitas DiponegoroSunariyah. 2006. Pengantar Pengetahuan Pasar Modal.

Gunawan, H., \& Ramdan, Z. (2012). Pengaruh Konflik Peran, Ketidakjelasan Peran, Kelebihan Peran, dan Gaya Kepemimpinan terhadap Kinerja Auditor Di Kantor Akuntan Publik Wilayah DKI Jakarta. Binus Business Review, 3(2), 825-839. https://doi.org/10.21512/bbr.v3i2.1365

Haines III, V. Y., Harvey, S., Durand, P., \& Marchand, A. (2013). Core Self-Evaluations, Work-Family Conflict, and Burnout. Journal of Marriage and Family, 75(3), 778-793. https://doi.org/10.1111/jomf.12026

Halim, A. (2008). Auditing (Dasar-dasar audit laporan keuangan). UUP STIM.

Harris, K. J., Harvey, P., \& Kacmar, K. M. (2009). Do social stressors impact everyone equally? An examination of the moderating impact of core self-evaluations. Journal of Business and Psychology, 24(2), 153-164. https://link.springer.com/article/10.1007/s10869-009-9096-2

Hartono, J. (2004). Metodologi Penelitian Bisnis: salah kaprah dan pengalaman-pengalaman. Yogyakarta: Bpfe. 
Hodgson, C. (2017). 'Big Four' accounts KPMG and PwC have both just been fined millions, Business Insider Business Insider Singapore, Bussiness Insider Singapore.

Hutami, G., \& Chariri, A. (2011). Pengaruh Konflik Peran dan Ambiguitas Peran Terhadap Komitmen Independensi Auditor Internal Pemerintah Daerah (Studi Empiris pada Inspektorat Kota Semarang) (Doctoral dissertation, Universitas Diponegoro). http://eprints.undip.ac.id/30903/

Indonesia, I. A. (2004). Standar Profesional Akuntan Publik, Jakarta: Salemba Empat. Ikatan Akuntan Indonesia.

Iqbal, Y. (2012). Impact of core self evaluation (cse) on job satisfaction in education sector of Pakistan. Journal of Global Strategic Management,6(2), 132-139. http://www.isma.info/uploads/files/132-impact-of-core-selfevaluation--cse--on-job-satisfaction-in-education-sector-of-pakistan.pdf

Jex, S. M., \& Elacqua, T. C. (1999). Self-esteem as a moderator: A comparison of global and organization-based measures. Journal of occupational and Organizational Psychology, 72(1), 71-81. https://doi.org/10.1348/096317999166509

Judge, T. A. (2009). Core self-evaluations and work success. Current Directions in Psychological Science, 18(1), 5862. https://doi.org/10.1111\%2Fj.1467-8721.2009.01606.x

Judge, T. A., \& Bono, J. E. (2001). Relationship of core self-evaluations traits—self-esteem, generalized selfefficacy, locus of control, and emotional stability-with job satisfaction and job performance: A metaanalysis. Journal of applied Psychology, 86(1), 80.

Judge, T. A., \& Klinger, R. (2008). Job satisfaction: Subjective well-being at work. In M. Eid \& R. J. Larsen (Eds.), The science of subjective well-being (pp. 393-413). New York, NY, US: Guilford Press. https://psycnet.apa.org/record/2008-00541-019

Judge, T. A., Erez, A., Bono, J. E., \& Thoresen, C. J. (2003). The core self-evaluations scale: Development of a measure. Personnel psychology, 56(2), 303-331. https://doi.org/10.1111/j.1744-6570.2003.tb00152.x

Judge, T. A., Ilies, R., \& Zhang, Z. (2012). Genetic influences on core self-evaluations, job satisfaction, and work stress: A behavioral genetics mediated model. Organizational Behavior and Human Decision Processes, 117(1), 208-220. https://doi.org/10.1016/j.obhdp.2011.08.005

Judge, T. A., Locke, E. A., Durham, C. C., \& Kluger, A. N. (1998). Dispositional effects on job and life satisfaction: The role of core evaluations. Journal of applied psychology, 83(1), 17.

Kamau, C. G. (2013). Determinants of audit expectation gap: Evidence from limited companies in Kenya. International Journal of Science and Research (IJSR, ) Volume, 2(1).

Karimi, R., Omar, Z. B., Alipour, F., \& Karimi, Z. (2014). The influence of role overload, role conflict, and role ambiguity on occupational stress among nurses in selected Iranian hospitals. International Journal of Asian Social Science, 4(1), 34-40. http://www.academia.edu/download/36392280/artice.pdf

Kaur, S. (2012). Effect of personality on organisational role stress: A case study of working women in Ludhiana. International Journal of Physical and Social Sciences, 2(4), 211-225.

Landy, F. J., \& Conte, J. M. (2016). Work in the 21st century, Binder ready version: An introduction to Industrial and Organizational Psychology. John Wiley \& Sons. https://books.google.co.id/books?hl=en\&lr=\&id=NIWbCgAAQBAJ\&oi

Love, K. A. (1987). Gender differences in occupational role conflict and psychological well-being, job satisfaction, job involvement and stress. http://hdl.handle.net/10092/12019

Lubis, A. M., Sandhow, L., Lubis, V. K., Noor, A., Gumay, F., Merlina, M., ... \& Susanto, N. H. (2011). Isolation and cultivation of mesenchymal stem cells from iliac crest bone marrow for further cartilage defect management. Acta Med Indones, 43(3), 178-84.

Margheim, L., Kelley, T., \& Pattison, D. (2005). An empirical analysis of the effects of auditor time budget pressure and time deadline pressure. The Journal of Applied Business Research,21(1), 23-36. https://doi.org/10.19030/jabr.v21i1.1497

Mo Koo, C., \& Seog Sim, H. (1999). On the role conflict of auditors in Korea. Accounting, Auditing \& Accountability Journal, 12(2), 206-219. https://doi.org/10.1108/09513579910270110

Nasurdin, A. M., Ramayah, T., \& Kumaresan, S. (2005). Organizational stressors and job stress among managers: The moderating role of neuroticism. Singapore Management Review, 27(2), 63-79. http://ramayah.com/journalarticlespdf/organizationalstressors.pdf

Okafor, C. A., \& Otalor, J. I. (2013). Narrowing the expectation gap in auditing: the role of the auditing profession. Research Journal of Finance Accounting, 4(2), 43-52. http://eprints.covenantuniversity.edu.ng/2809/

Kesuma, I. B. G. P. W., \& Dwirandra, A. (2019). Professional commitments and pressure of obedience in mediating on the effect of time budget pressure in quality audits. International Research Journal of Engineering, IT \& Scientific Research, 5(1), 27-38. https://doi.org/10.21744/irjeis.v5n1.587 
Purnomo, R., \& Lestari, S. (2010). Pengaruh kepribadian, self-efficacy, dan locus of control terhadap persepsi kinerja usaha skala kecil dan menengah. Jurnal Bisnis dan Ekonomi, 17(2). https://www.unisbank.ac.id/ojs/index.php/fe3/article/download/333/217

Rahmania, P. N., \& Yuniar, I. C. (2012). Hubungan antara self-esteem dengan kecenderungan body dysmorphic disorder pada remaja putri. Jurnal psikologi klinis dan kesehatan mental, 1(02), 110-117. http://www.journal.unair.ac.id/filerPDF/jpkk76a52dc72afull.pdf

Rizwan, M., Tariq, M. A., Hussain, S., Rashid, R. M., Hussain, M. S., \& Khawar, I. H. (2013). Antecedents of job stress and its impact on job satisfaction. Asian Journal of Empirical Research,3(2), 175-190. https://ideas.repec.org/a/asi/ajoerj/2013p175-190.html

Rizzo, J. R., House, R. J., \& Lirtzman, S. I. (1970). Role conflict and ambiguity in complex organizations. Administrative science quarterly, 150-163. https://doi.org/10.2307/2391486

Robbins, S. P., \& Judge, T. A. (2001). Organizational behavior. https://wiki.webscience.thkoeln.de/index.php?title=Organizational_Behavior\&diff $=11616 \&$ oldid $=11615$

Roberts, J. A., Lapidus, R. S., \& Chonko, L. B. (1997). Salespeople and stress: The moderating role of locus of control on work stressors and felt stress. Journal of Marketing Theory and Practice, 5(3), 93-108. https://doi.org/10.1080/10696679.1997.11501773

Rotter, J. B. (1966). Generalized expectancies for internal versus external control of reinforcement. Psychological monographs: General and applied, 80(1), 1. https://psycnet.apa.org/doi/10.1037/h0092976

Ruhnke, K., \& Schmidt, M. (2014). The audit expectation gap: existence, causes, and the impact of changes. Accounting and Business research, 44(5), 572-601. https://doi.org/10.1080/00014788.2014.929519

Safaria, T., bin Othman, A., \& Wahab, M. N. A. (2011). The Role of Leadership Practices on Job Stress among Malay Academic Staff: A Structural Equation Modeling Analysis. International Education Studies, 4(1), 90-100. https://eric.ed.gov/?id=EJ1066419

Salehi, M. (2009). Non-Audit Service and Audit Independence: Evidences from Iran. International Journal of Business and Management, 4(2), 142.

Sanders, G., Allen, A., \& Korte, L. (1995). Municipal audit fees: Has increased competition made a difference?. Auditing, 14(1), https://search.proquest.com/openview/901e41f4f5d26609b6b9d7f2ccc2d0a2/1?pq-origsite=gscholar\&cbl=31718

Settles, I. H., Sellers, R. M., \& Damas Jr, A. (2002). One role or two?: The function of psychological separation in role conflict. Journal of Applied Psychology, 87(3), 574. https://psycnet.apa.org/doi/10.1037/0021-9010.87.3.574

Smith, E. E. 2010. Ten Careers with High Rates of Depression, Psychologytoday. https://www.psychologytoday.com/blog/not-born-yesterday/201011/ten-careers-high-rates-depression

Spickernell, S. 2015. The Stress of Accounting: One in Three UK Accountants has Suffered Mental Health Problems, CityA.M. http://www.cityam.com/225737/stress-finance-one-three-uk-accountants-has-sufferedmental-health-problems

Spillane, R. (1987). How auditors can manage stress and motivation. Managerial auditing journal, 2(2), 26-28. https://doi.org/10.1108/eb017594

Suarditha, I. N. G., Dwirandra, A. B., \& Badera, I. D. N. (2017). Kemampuan Pengawas Internal dan Gaya Kepemimpinan Memoderasi Pengaruh Partisipasi Penganggaran dan Profesionalisme pada Senjangan Anggaran Pemerintah Provinsi Bali. E-Jurnal Ekonomi dan Bisnis Universitas Udayana. https://ojs.unud.ac.id/index.php/EEB/article/view/23230

Sugiyono. (2009). Metode Penelitian Bisnis. Bandung: Alfabeta Bandung.

Tang, Y. T., \& Chang, C. H. (2010). Impact of role ambiguity and role conflict on employee creativity. African Journal of Business Management, 4(6), 869-881. https://academicjournals.org/journal/AJBM/articleabstract/8F7ED1023503

Tavousi, M. N. (2015). Dispositional Effects on Job Stressors and Job Satisfaction: The Role of Core Evaluations. Procedia-Social and Behavioral Sciences, 190, 61-68. https://doi.org/10.1016/j.sbspro.2015.04.917

Utama, S. (2011). An evaluation of support infrastructures for corporate responsibility reporting in Indonesia. Asian Business \& Management, 10(3), 405-424. https://link.springer.com/article/10.1057/abm.2011.10

Vanishree, P. (2014). Impact of role ambiguity, role conflict and role overload on job stress in small and medium scale industries. Research Journal of Management Sciences, 3(1), 10-13.

Wibowo, A., Becker, C., Marconi, G., Durr, J., Price, J., Hagmann, J., ... \& Weigel, D. (2016). Hyperosmotic stress memory in Arabidopsis is mediated by distinct epigenetically labile sites in the genome and is restricted in the 
male germline by DNA glycosylase activity. Elife, 5, e13546. https://cdn.elifesciences.org/articles/13546/elife13546-v1.pdf

Wirama, D. G., Wirakusuma, M. G., \& Damayanti, N. N. S. R. (2015). Pengaruh Core Self Evaluations pada Kinerja Auditor Badan Pemeriksa Keuangan Republik Indonesia Perwakilan Provinsi Bali. E-Jurnal Ekonomi dan Bisnis Universitas Udayana, 4. https://ojs.unud.ac.id/index.php/EEB/article/view/12534

Yongkang, Z., Weixi, Z., Yalin, H., Yipeng, X., \& Liu, T. (2014). The relationship among role conflict, role ambiguity, role overload and job stress of Chinese middle-level cadres. Chinese Studies, 3(01), 8. http://dx.doi.org/10.4236/chnstd.2014.31003

Yuen, D. C., Law, P. K., Lu, C., \& Qi Guan, J. (2013). Dysfunctional auditing behaviour: empirical evidence on auditors' behaviour in Macau. International Journal of Accounting \& Information Management, 21(3), $209-226$. https://doi.org/10.1108/IJAIM-12-2012-0075

Zhou, Y., Lu, J., Liu, X., Zhang, P., \& Chen, W. (2014). Effects of core self-evaluations on the job burnout of nurses: the mediator of organizational commitment. PloS one, 9(4), e95975. https://doi.org/10.1371/journal.pone.0095975

Zorlu, K. (2012). The perception of self-esteem and self-efficacy as transforming factors in the sources of role stress and job satisfaction relationship of employees: A trial of a staged model based on the artificial neural network method. African Journal of Business Management, 6(8), 3014-3025. https://doi.org/10.5897/AJBM11.2345

Kesuma, I. B. G. P. W., \& Dwirandra, A. (2019). Professional commitments and pressure of obedience in mediating on the effect of time budget pressure in quality audits. International Research Journal of Engineering, IT \& Scientific Research, 5(1), 27-38. https://doi.org/10.21744/irjeis.v5n1.587 


\section{Biography of Authors}

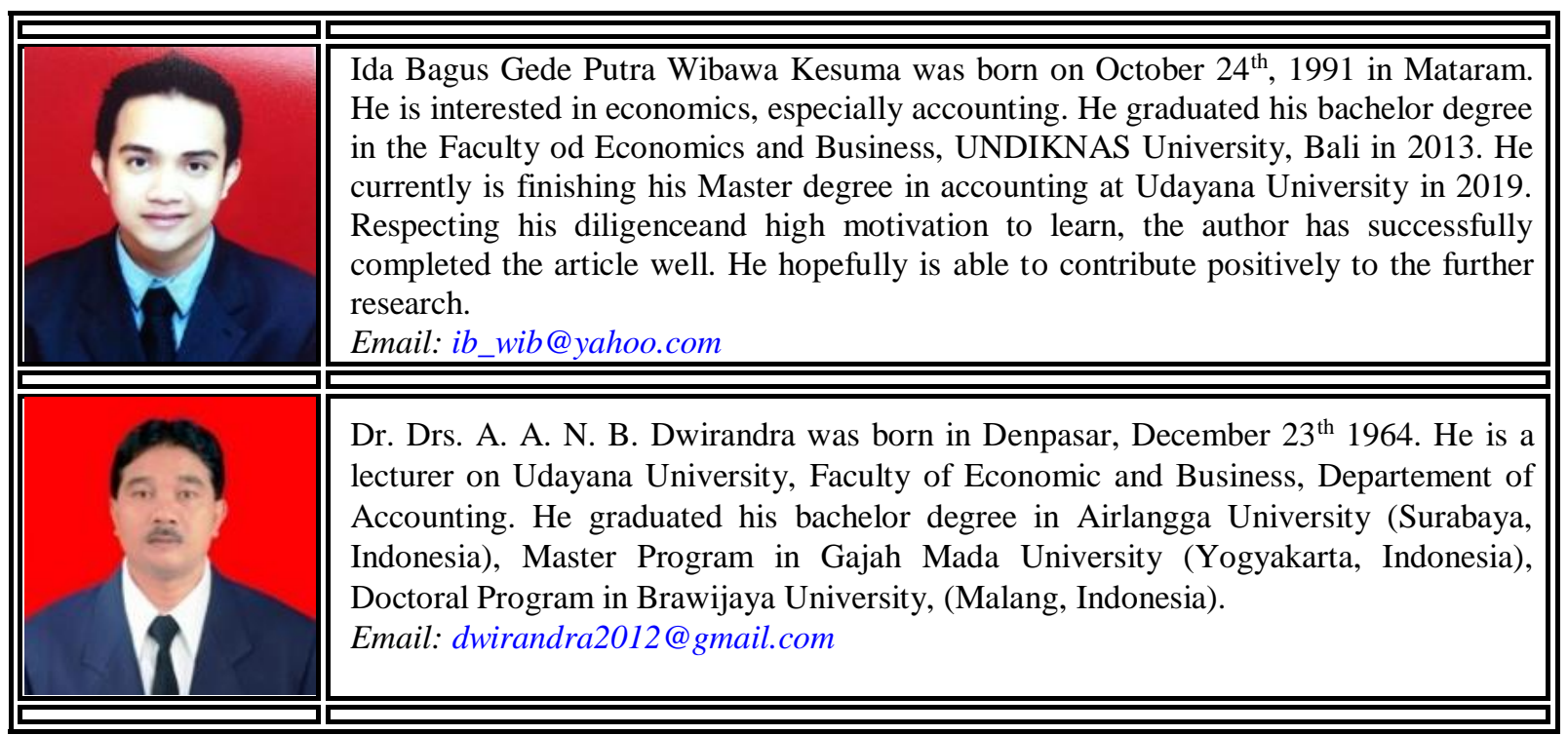

